(RESEARCH ARTICLE)

\title{
The role of Ascaridia columbae in bioremediation of heavy metal accumulation in Columba livia tissues
}

\author{
Abdel-Gaber Rewaida 1, 2, *, Alzuabi Khulud 1 and Abdel-Gaber Rania ${ }^{2}$ \\ ${ }^{1}$ Zoology Department, College of Science, King Saud University, Riyadh, Saudi Arabia. \\ 2 Zoology Department, Faculty of Science, Cairo University, Cairo, Egypt.
}

Publication history: Received on 22 March 2020; revised on 28 March 2020; accepted on 30 March 2020

Article DOI: https://doi.org/10.30574/wjarr.2020.5.3.0075

\begin{abstract}
Pigeons are susceptible to various pollutants. The purpose of this study was to determine the role of nematode parasites in the bioremediation of metal accumulation in domestic pigeon Columba livia. A total of 26 domestic pigeons from poultry farm in Riyadh, Saudi Arabia; were collected randomly. The concentration of elements in infected and noninfected pigeons was measured using inductively coupled plasma mass spectrometer. The levels of the metal varied that depending on different tissues. During this study, zinc was measured as the dominant metal. Overall, the results showed that all heavy metals concentrations in liver samples were significantly higher than in other pigeon tissues. Nematodes have been collected and described in the intestinal tract of pigeons. The results showed that intestinal nematode parasites in the tissues of infected pigeons caused a significant decrease in metal concentrations compared to noninfected ones. Bioaccumulation factors have shown that nematode parasites have a higher concentration potential than pigeon tissues. Adult nematode infection in domestic pigeons is considered a biomarker of heavy metal contamination, and its presence reduced the biosynthesis of heavy metals in pigeon tissues.
\end{abstract}

Keywords: Columba livia; Ascaridia species; Biological indicators

\section{Introduction}

Birds are good subjects for pollution studies because they have high trophic levels, are well studied, easy to detect, and are indicators of environmental health [1,2]. Due to anthropogenic activities, heavy metals are often mobilized faster than normal in birds and environments [3]. Prolonged exposure to contaminants over time can result in physiological, behavioral, and biochemical changes in hosts, which may ultimately influence the spread and severity of parasitic diseases $[4,5,6]$.

The ability to bioaccumulate by the parasites arising from the competition for chemical elements, including heavy metals which is a valuable tool for evaluating the functions of the parasite-host system [7]. Previous studies describe a higher concentration of different heavy metals in different parasites than host tissue and the possibility of bioaccumulation of parasites to reduce heavy metals concentration in their hosts [8]. With regard to urban ecosystems, data on the use of parasites as potential bio-indicators for heavy metal pollution are still very scarce and apply exclusively to cestode/mammal models [9,10]. While, models have been proposed for water birds [11] or raptors [12], but no data on urban birds are available.

In Saudi Arabia, the nematode Ascaridia columbae is one of the most common helminthes for pigeons. Since, nematode/pigeon systems were never evaluated, the main objective of this study was to evaluate the accumulation of trace elements in A. columbae and in Columba livia tissues in Riyadh, Saudi Arabia, and therefore to evaluate the A. columbae/C. livia model as another promising bioindicator system.

\footnotetext{
* Corresponding author: Abdel-Gaber Rewaida
}

Copyright (C) 2020 Author(s) retain the copyright of this article. This article is published under the terms of the Creative Commons Attribution Liscense 4.0. 


\section{Material and methods}

A total of 26 of the domestic pigeon, Columba livia, were accidentally picked from a poultry farm in Riyadh, Saudi Arabia. The pigeons were taken to the laboratory and then dissected and examined for the presence of endoparasites under a dissecting microscope. Helminthes were collected from infected organs using a pipette and washed several times to remove residues and mucus in saline petri dishes. Based on taxonomic keys, parasites were identified based on their morphological properties. Based on the protocol mentioned in UNEP/FAO/IOC/IAEA [13], both parasite and pigeon tissues were removed and analyzed separately to detect heavy metals. The samples were digested with concentrated nitric acid and perchloric acid $(2: 1 \mathrm{v} / \mathrm{v})$ for 3 days at $60^{\circ} \mathrm{C}$. After complete digestion, the samples were diluted with bidistilled $\mathrm{H}_{2} \mathrm{O}$ and then analyzed for trace elements in an inductively coupled plasma mass spectrometer (Varian Model-Liberty Series II, Analytical West, Inc., Corona, California, USA). The values of all observed heavy metals are given in $\mathrm{mg} / \mathrm{g}$ wet-weight in comparison to the values determined by FAO/WHO [14].

Absorption wavelengths and detection limits for heavy metals using an Elbert mount diffraction grating monochromator (Horbia Scientific, NJ, USA) were $188.980 \mathrm{~nm}$ and $0.16 \mathrm{ppm}$ for As, $214.439 \mathrm{~nm}$ and $0.04 \mathrm{ppm}$ for Cd, $267.716 \mathrm{~nm}$ and $0.04 \mathrm{ppm}$ for $\mathrm{Cr}, 327.395 \mathrm{~nm}$ and $0.05 \mathrm{ppm}$ for $\mathrm{Cu}, 257.610 \mathrm{~nm}$ and $0.05 \mathrm{ppm}$ for $\mathrm{Mn}, 220.353 \mathrm{~nm}$ and $0.13 \mathrm{ppm}$ for $\mathrm{Pb}, 196.026 \mathrm{~nm}$ and $0.09 \mathrm{ppm}$ for $\mathrm{Se}, 213.857 \mathrm{~nm}$ and $0.04 \mathrm{ppm}$ for $\mathrm{Zn}, 231.604 \mathrm{~nm}$ and $0.001 \mathrm{ppm}$ for $\mathrm{Ni}$, $238.204 \mathrm{~nm}$ and $0.01 \mathrm{ppm}$ for Fe, $279.553 \mathrm{~nm}$ and $0.01 \mathrm{ppm}$ for $\mathrm{Mg}, 396.152 \mathrm{~nm}$ and $0.12 \mathrm{ppm}$ for Al, $455.403 \mathrm{~nm}$ and $0.16 \mathrm{ppm}$ for $\mathrm{Ba}, 238.892 \mathrm{~nm}$ and $0.02 \mathrm{ppm}$ for Co, $202.032 \mathrm{~nm}$ and $0.05 \mathrm{ppm}$ for Mo, $407.771 \mathrm{~nm}$ and $0.13 \mathrm{ppm}$ for Sr.

In addition, the bioaccumulation factor (BAF) was determined to quantify the bioaccumulation of heavy metals in pigeon tissues, according to Sures et al. [7]. All data from the experiment were presented as means \pm SE and underwent a oneway analysis of variance test (ANOVA) in which significant relationships between heavy metal accumulation in parasite and pigeon tissues were identified. All statistical procedures were performed using SPSS statistics 16.0 software (SPSS Inc., Chicago, IL, USA) and Duncan's multiple range tests. When p-values were $<0.01$ and $<0.05$, variations were considered significant.

\section{Results}

Based on the taxonomic keys, nematodes are identified according to their morphological characteristics as Ascaridia columbae. The distribution of elements in the host-parasite system presented in Table (1). Pigeons infected with intestinal nematodes have a significant decrease in the elements compared to non-infected ones. The concentration of metals in the tissues of the infected pigeon was $\mathrm{Zn}>\mathrm{Al}>\mathrm{Mg}>\mathrm{Cu}>\mathrm{Sr}>\mathrm{Ni}>\mathrm{Ba}>\mathrm{Cd}>\mathrm{Fe}>\mathrm{Se}>\mathrm{Mn}>\mathrm{Mo}>\mathrm{Co}>\mathrm{Cr}>\mathrm{Pb}$ $>$ As. The ability of tissues of infected pigeon for the collection of different metals were found in the following order: ovary $>$ pancreas $>$ kidney $>$ feather $>$ liver $>$ lung $>$ muscle $>$ heart $>$ testes.

In all the elevated host tissues, Zn was the dominant element. Liver accumulates in large quantities compared to other tissues. The heart was the main place for accumulation of Mg. In comparison to other tissues, the highest mean concentrations of As and $\mathrm{Al}$ were found in the kidney. In addition, in the kidney and feather, Mn was prominent. Fe and Co increased significantly in the lungs. In contrast to other pigeon tissues, the ovary contains $\mathrm{Cr}, \mathrm{Cu}, \mathrm{Pb}, \mathrm{Ni}, \mathrm{Fe}, \mathrm{Mg}, \mathrm{Al}$, $\mathrm{Ba}, \mathrm{Co}, \mathrm{Mo}$, and $\mathrm{Sr}$ that accumulated significantly in large quantities. On the other hand, it is observed that other metals of As, Cd, Cr, Se, Ni, Co and Mo accumulate in feather. The remaining elements ( $\mathrm{Cd}, \mathrm{Cu}, \mathrm{Pb}, \mathrm{Se}, \mathrm{Ba}$, and $\mathrm{Sr}$ ) increased significantly in the pancreas have. Muscles and testes are the lower organs for the accumulation of metals. The heavy metal concentrations found in the parasites were significantly higher than in the tissues of the host pigeons, and were ordered as follows: $\mathrm{Sr}>\mathrm{Mn}>\mathrm{Zn}>\mathrm{Mg}>\mathrm{Al}>\mathrm{Mo}>\mathrm{Se}>\mathrm{Ni}>\mathrm{Cd}>\mathrm{Ba}>\mathrm{Cr}>\mathrm{As}>\mathrm{Cu}>\mathrm{Pb}>\mathrm{Co}>\mathrm{Fe}$. The concentrations of these metals are generally at dangerous levels which exceeded the acceptable limits prescribed by the US Environmental Protective Agency.

The differences found among the majority of the heavy metal density in various tissues and parasites of pigeons are significant (Table 2). This showed that in parasitic nematodes, the capacity to accumulate heavy metals was significantly higher than the apparent difference in the tissues of its host. As a result, the ratio (C[nematode parasite]/C[pigeon tissue]) for the most essential elements was higher than 0.5, with the following order $\mathrm{Mn}>\mathrm{Se}>\mathrm{Cd}>\mathrm{Mo}>\mathrm{Ba}>\mathrm{Cr}>\mathrm{As}$ $>\mathrm{Sr}>\mathrm{Co}>\mathrm{Ni}>\mathrm{Zn}>\mathrm{Pb}>\mathrm{Cu}>\mathrm{Mg}>\mathrm{Al}>\mathrm{Fe}$. In addition, $\mathrm{Mn}$ (BAF=7948.6) yielded the highest bioaccumulation factor, which gave higher accumulation ratio between parasite and pigeon tissues higher than other elements. 
Table 1 Effect of parasitic infestation on trace element concentrations ( $\mu \mathrm{g} / \mathrm{g}$ wet weight) in infected pigeon organs as well as in parasitic nematode A. columbae

\begin{tabular}{|c|c|c|c|c|c|c|c|c|c|c|}
\hline \multirow{2}{*}{$\begin{array}{l}\text { Trace } \\
\text { element }\end{array}$} & \multicolumn{9}{|c|}{ Different host tissues } & \multirow{2}{*}{ A. columbae } \\
\hline & Liver & Kidney & Heart & Lung & Muscles & Pancreas & Ovary & Testes & Feather & \\
\hline As & $0.66 \pm 0.07 \mathrm{c}$ & $2.93 \pm 0.3 \mathrm{bc}$ & $0.17 \pm 0.13^{c}$ & $0.54 \pm 0.04^{c}$ & $1.27 \pm 0.04^{c}$ & $0.63 \pm 0.04 \mathrm{c}$ & $0.71 \pm 0.08^{c}$ & $1.26 \pm 0.05^{c}$ & $7.54 \pm 3.58^{b}$ & $83.59 \pm 4.17$ a \\
\hline $\mathrm{Cd}$ & $0.26 \pm 0.03 \mathrm{c}$ & $0.22 \pm 0.07 \mathrm{c}$ & $0.29 \pm 0.08 \mathrm{c}$ & $0.95 \pm 0.34^{c}$ & $1.47 \pm 0.49 \mathrm{c}$ & $3.63 \pm 1.13 \mathrm{c}$ & $2.69 \pm 1.05^{c}$ & $0.64 \pm 0.17 \mathrm{c}$ & $38.15 \pm 6.29 \mathrm{~b}$ & $132.61 \pm 11.64$ \\
\hline $\mathrm{Cr}$ & $1.37 \pm 1.13 \mathrm{~b}$ & $1.69 \pm 0.49 \mathrm{~b}$ & $0.32 \pm 0.73 \mathrm{~b}$ & $0.51 \pm 0.08^{b}$ & $0.53 \pm 0.19 \mathrm{~b}$ & $2.72 \pm 1.01 \mathrm{~b}$ & $3.62 \pm 1.13 \mathrm{~b}$ & $0.41 \pm 0.09 \mathrm{~b}$ & $8.01 \pm 2.06^{b}$ & $100.47 \pm 10.80$ \\
\hline $\mathrm{Cu}$ & $12.7 \pm 1.2 \mathrm{~cd}$ & $9.44 \pm 0.8 \mathrm{de}$ & $4.62 \pm 0.59$ ef & $4.62 \pm 0.55^{\text {ef }}$ & $13.01 \pm 2.1^{\mathrm{cd}}$ & $23.27 \pm 3.68^{b}$ & $18.64 \pm 3.26^{b c}$ & $3.33 \pm 0.01$ ef & $0.15 \pm 0.03^{\mathrm{f}}$ & $62.65 \pm 4.58$ a \\
\hline Mn & $3.78 \pm 1.15^{b}$ & $8.77 \pm 1.43 \mathrm{~b}$ & $0.06 \pm 0.01 \mathrm{~b}$ & $2.66 \pm 1.82^{b}$ & $0.15 \pm 0.03 \mathrm{~b}$ & $2.52 \pm 1.03 \mathrm{~b}$ & $0.02 \pm 0.002^{b}$ & $0.40 \pm 0.13^{b}$ & $9.43 \pm 1.51 \mathrm{~b}$ & $729.86 \pm 29.66^{a}$ \\
\hline $\mathrm{Pb}$ & $1.79 \pm 0.82 \mathrm{~b}$ & $1.14 \pm 0.21 \mathrm{~b}$ & $1.04 \pm 0.14 \mathrm{~b}$ & $0.86 \pm 0.13 \mathrm{~b}$ & $1.55 \pm 0.51 \mathrm{~b}$ & $4.86 \pm 1.47 \mathrm{~b}$ & $7.12 \pm 1.32 \mathrm{~b}$ & $0.18 \pm 0.08 \mathrm{~b}$ & $0.46 \pm 0.10^{b}$ & $57.65 \pm 6.49$ a \\
\hline $\mathrm{Se}$ & $1.97 \pm 0.50 \mathrm{~b}$ & $0.90 \pm 0.32 \mathrm{~b}$ & $0.04 \pm 0.02 \mathrm{~b}$ & $3.72 \pm 1.15^{b}$ & $2.28 \pm 0.51 \mathrm{~b}$ & $9.13 \pm 2.60 \mathrm{~b}$ & $7.06 \pm 1.79 \mathrm{~b}$ & $0.16 \pm 0.06^{b}$ & $7.15 \pm 1.37 \mathrm{~b}$ & $183.97 \pm 8.90$ a \\
\hline Zn & $86.98 \pm 7.3 \mathrm{~b}$ & $48.8 \pm 6.2 \mathrm{~cd}$ & $16.11 \pm 1.3$ e & $25.81 \pm 3.2 \mathrm{de}$ & $25.72 \pm 2.6$ de & $54.96 \pm 7.24^{\mathrm{c}}$ & $101.23 \pm 10.6^{b}$ & $15.86 \pm 2.01 \mathrm{e}$ & $0.58 \pm 0.21^{\mathrm{f}}$ & $394.50 \pm 22.57$ \\
\hline $\mathrm{Ni}$ & $1.01 \pm 0.13^{c}$ & $3.47 \pm 0.71^{c}$ & $0.77 \pm 0.08 \mathrm{c}$ & $1.31 \pm 0.12^{\mathrm{c}}$ & $2.79 \pm 0.22^{c}$ & $4.71 \pm 0.519 \mathrm{c}$ & $5.60 \pm 0.19 c$ & $1.11 \pm 0.14^{\mathrm{c}}$ & $33.70 \pm 7.92 \mathrm{~b}$ & $173.83 \pm 12.21$ \\
\hline $\mathrm{Fe}$ & $4.14 \pm 1.44 \mathrm{~d}$ & $4.85 \pm 0.9 \mathrm{~cd}$ & $4.15 \pm 0.97 \mathrm{~d}$ & $9.42 \pm 1.79 c$ & $1.53 \pm 0.58 \mathrm{~d}$ & $2.58 \pm 0.95 \mathrm{~d}$ & $15.10 \pm 3.36^{b}$ & $0.98 \pm 0.30 \mathrm{~d}$ & $3.63 \pm 1.16^{\mathrm{d}}$ & $22.34 \pm 2.05^{\mathrm{a}}$ \\
\hline Mg & $6.49 \pm 1.44^{c}$ & $12.27 \pm 2.6^{c}$ & $22.96 \pm 2.04^{\mathrm{c}}$ & $6.73 \pm 1.66^{c}$ & $10.04 \pm 1.5^{c}$ & $21.39 \pm 3.82^{c}$ & $53.91 \pm 8.12^{b}$ & $8.70 \pm 1.89^{c}$ & $16.87 \pm 2.11^{\mathrm{c}}$ & $337.12 \pm 26.11$ \\
\hline $\mathrm{Al}$ & $19.67 \pm 4.6^{d}$ & $76.99 \pm 8.7 \mathrm{~b}$ & $18.24 \pm 3.6^{d}$ & $63.55 \pm 9.6^{b}$ & $30.93 \pm 7.2 \mathrm{~cd}$ & $60.32 \pm 6.1 \mathrm{cb}$ & $65.57 \pm 8.89 \mathrm{~b}$ & $19.47 \pm 4.23 \mathrm{~d}$ & $5.52 \pm 1.74 \mathrm{~d}$ & $245.44 \pm 138.6^{\circ}$ \\
\hline $\mathrm{Ba}$ & $2.18 \pm 0.82 \mathrm{~b}$ & $5.44 \pm 1.76^{b}$ & $2.13 \pm 0.99 \mathrm{~b}$ & $4.84 \pm 2.01 \mathrm{~b}$ & $7.96 \pm 2.45 \mathrm{~b}$ & $12.21 \pm 4.08^{b}$ & $14.41 \pm 5.28 \mathrm{~b}$ & $3.36 \pm 1.24 \mathrm{~b}$ & $0.07 \pm 0.01 \mathrm{~b}$ & $128.92 \pm 20.44$ \\
\hline Co & $0.22 \pm 0.09 \mathrm{c}$ & $0.67 \pm 0.15^{c}$ & $0.21 \pm 0.14 \mathrm{c}$ & $4.28 \pm 3.85 \mathrm{bc}$ & $1.58 \pm 0.59 \mathrm{bc}$ & $1.29 \pm 0.77 \mathrm{bc}$ & $2.21 \pm 0.87 \mathrm{bc}$ & $0.45 \pm 0.22^{c}$ & $13.09 \pm 7.58 \mathrm{~b}$ & $35.83 \pm 8.03$ a \\
\hline Mo & $1.98 \pm 0.84 \mathrm{~b}$ & $2.41 \pm 1.18^{b}$ & $0.31 \pm 0.09 \mathrm{~b}$ & $1.10 \pm 0.59 \mathrm{~b}$ & $0.37 \pm 0.17^{b}$ & $3.33 \pm 1.38 \mathrm{~b}$ & $4.64 \pm 1.178^{b}$ & $0.94 \pm 0.31^{b}$ & $10.57 \pm 1.69 \mathrm{~b}$ & $214.72 \pm 23.93$ \\
\hline $\mathrm{Sr}$ & $2.70 \pm 0.99 \mathrm{~b}$ & $4.75 \pm 2.26^{\mathrm{b}}$ & $1.71 \pm 0.55^{b}$ & $4.53 \pm 1.41^{b}$ & $6.83 \pm 1.66^{\mathrm{b}}$ & $12.36 \pm 2.82^{b}$ & $12.77 \pm 3.57^{\mathrm{b}}$ & $2.76 \pm 1.13^{b}$ & $8.22 \pm 5.54 \mathrm{~b}$ & $969.00 \pm 35.08$ \\
\hline
\end{tabular}


Table 2 Mean and range of accumulation factors $[\mathrm{C}]_{\text {parasite }} /[\mathrm{C}]_{\text {pigeon tissue }}$ for trace elements detected in A. columbae in relation to C. livia tissues

\begin{tabular}{|c|c|c|c|c|c|c|c|c|c|}
\hline \multirow{2}{*}{$\begin{array}{l}\text { Trace } \\
\text { element }\end{array}$} & \multicolumn{9}{|c|}{ Accumulation factors $[\mathrm{C}]_{\text {parasite }} /[\mathrm{C}]_{\text {host tissue }}$} \\
\hline & Liver & Kidney & Heart & Lung & Muscles & Pancreas & Ovary & Testes & Feather \\
\hline As & $132.59^{* *}$ & 29.378 & 521.08 & $164.39 *$ & $62.457^{* *}$ & 126.73 & $124.93^{*}$ & 66.967 & $9.2780^{* *}$ \\
\hline $\mathrm{Cd}$ & 518.61 & 714.79 & $462.77^{*}$ & 248.52 & 112.56 & $41.824^{*}$ & $56.573^{* *}$ & $239.56^{*}$ & 3.4970 \\
\hline $\mathrm{Cr}$ & $350.11^{*}$ & $67.809^{* *}$ & 281.57 & $204.82^{*}$ & $190.56^{*}$ & $37.861^{*}$ & $30.604^{* *}$ & 242.06 & $12.833^{*}$ \\
\hline $\mathrm{Cu}$ & 4.8520 & 6.4044 & $14.333^{* *}$ & 13.986 & 4.9534 & 2.6802 & 3.5640 & $18.548^{*}$ & $410.83^{* *}$ \\
\hline Mn & $211.96^{*}$ & $90.656^{* *}$ & 1210.4 & $2124.7^{*}$ & $4608.1^{*}$ & $377.01 *$ & $7948.6^{*}$ & 1899.1 & 73.698* \\
\hline $\mathrm{Pb}$ & 46.791 & 38.427 & $51.004^{* *}$ & $64.544^{*}$ & 45.116 & 13.942 & $8.1730^{*}$ & $169.10^{*}$ & $134.34^{* *}$ \\
\hline $\mathrm{Se}$ & $114.69^{*}$ & $280.96^{* *}$ & 1660.9 & 54.610 & $88.295^{*}$ & $20.931^{* *}$ & $25.677^{* *}$ & $1468.2^{*}$ & $26.009^{*}$ \\
\hline $\mathrm{Zn}$ & 4.6634 & 8.6093 & $26.479^{* *}$ & $15.963^{*}$ & $15.994^{*}$ & 7.2553 & 3.2345 & 26.826 & 719.29 \\
\hline $\mathrm{Ni}$ & $174.83^{* *}$ & $51.406^{*}$ & 228.82 & $133.41^{* *}$ & 60.806 & $37.218^{* *}$ & $31.727^{*}$ & $155.62^{*}$ & $5.5769^{*}$ \\
\hline $\mathrm{Fe}$ & 6.3571 & 4.6153 & $5.8746^{* *}$ & $2.6680^{*}$ & $18.033^{* *}$ & 9.0316 & 1.5977 & 26.713 & 6.6989* \\
\hline Mg & $53.672^{*}$ & $26.460^{* *}$ & 14.532 & 47.282 & 34.621 & $16.454^{*}$ & 5.9691 & $36.733^{*}$ & 15.411 \\
\hline $\mathrm{Al}$ & 12.680 & 3.1049 & $14.385^{* *}$ & $3.7257^{*}$ & $8.2375^{* *}$ & 4.0253 & 3.6711 & $12.626^{*}$ & $44.130^{* *}$ \\
\hline $\mathrm{Ba}$ & $74.311^{* *}$ & 28.070 & 94.238 & $33.0733^{*}$ & $20.874^{*}$ & $12.383^{*}$ & $12.693^{*}$ & 58.563 & $1773.5^{*}$ \\
\hline Co & 188.74 & $49.847^{*}$ & $530.05^{* *}$ & 45.140 & 22.782 & 47.044 & 18.515 & $60.386^{*}$ & 7.2763 \\
\hline Mo & $155.73^{*}$ & 101.98 & 835.05 & $225.99^{* *}$ & $571.82^{* *}$ & $62.283^{* *}$ & $48.708^{* *}$ & 244.04 & $20.225^{*}$ \\
\hline $\mathrm{Sr}$ & $241.06^{*}$ & $100.58^{* *}$ & $319.90^{*}$ & $98.046^{*}$ & 69.566 & 44.972 & $44.069^{* *}$ & $195.47^{* *}$ & $48.004^{*}$ \\
\hline
\end{tabular}

\section{Discussion}

The metal concentrations of intestinal parasites is compared to that of its host organs, indicating that it accumulates heavy metals in concentration, which have higher orders than its pigeon hosts. Such results were agreed with Sures [15] and later by Eissa et al. [16] whom reported that parasites accumulate large amounts of toxic metals in their bodies, thus acting as metal sinks for their hosts and helping them survive in the presence of toxins. Moreover, Azmat et al. [17] reported high levels of toxic metals in Echinocephalus sp. and Ascaris sp. in its host suggested that these parasitic nematodes can be used as environmentally sensitive indicators for heavy metals. In addition, Madanire-Moyo and Barson [18] reported that parasites are excellent indicators of environmental conditions.

This research showed that the ovary was a major target organ, which received the largest amount of heavy metals from the pigeon body. A possible explanation for this is the existence of high amounts of $\mathrm{Pb}$, consistent with Forstner and Wittmann [19], who demonstrated that $\mathrm{Pb}$ has an effect on the permeability of the membrane of host organs, where it inhibits the biosynthesis of heme and induces functional disruption or degradation of these tissues. The increased concentration of elements in host muscles during infection can be caused by the host's compensatory response [20].

With respect to the essential elements, higher concentrations of $\mathrm{Zn}$ are frequently detected without any toxic effect on the health of the organism. In addition, $\mathrm{Zn}$ can reduce its toxicity in contact with specific toxic elements such as $\mathrm{Cd}$ and $\mathrm{Pb}$ [21]. In the present investigation, the distribution of $\mathrm{Zn}$ in different organs of infected pigeons was in agreement with Pourang [22] who studied the accumulation of several heavy metals in Esox lucius and Carassius auratus from Anzali wetland. On the other hand, higher concentrations of $\mathrm{Cu}$ are usually toxic [23]. As, Bireš et al. [24] have shown that $\mathrm{Zn}$ prevents the accumulation of $\mathrm{Cu}$ in animal tissues and, therefore, provides some protection against the toxic effects of $\mathrm{Cu}$. The most affected element here was $\mathrm{Fe}, \mathrm{Cu}, \mathrm{Zn}, \mathrm{Mn}$, and $\mathrm{Co}$, which are lower in the host muscles. This indicated that the essential pathogenic effect of parasitic infection on the quality and usable biomass of the host, this agreed with Baruš et al. [25]. In the present study, the mean concentrations of $\mathrm{Cu}, \mathrm{Ni}, \mathrm{Cd}, \mathrm{Se}, \mathrm{Mo}, \mathrm{Co}, \mathrm{Cr}$, and As were found to be higher in 
pigeon feathers compared to soft tissues. This was accepted with Ek et al. [26] stated that the concentration of the metals in the feather is usually due to external contamination and the internal metabolism of trace elements.

In non-infected pigeons, the bioaccumulation of different metals in different organs was higher than in infected ones. Several studies have documented a reduction in the levels of some elements in parasitized host, including Fe [27], Ca, $\mathrm{Na}$, and $\mathrm{Mg}$ [25], $\mathrm{Zn}$ [28], $\mathrm{Cu}$ [29], and $\mathrm{Pb}$ [30] these are similar to the results described here, in that intestinal nematode parasites have a higher metal bioaccumulation efficiency compared to pigeon tissues.

\section{Conclusion}

Particular pigeon nematode parasites from the terrestrial environment may accumulate toxic metals. Therefore, the application of certain parasites as sentinel organisms could provide a new promise of environmental science for future research.

\section{Compliance with ethical standards}

\section{Acknowledgments}

Authors extend their appreciation to College of Science in King Saud University for providing all facilities to complete this work.

\section{Disclosure of conflict of interest}

The authors declare that they have no conflict of interest regarding the content of this article.

\section{Statement of ethical approval}

The present research work does not contain any studies performed on animal subjects by any of the authors.

\section{Statement of informed consent}

Informed consent was signed to all respondents before the data collection.

\section{References}

[1] Nam DH, Lee DP and Koo TH. (2004). Factors causing variations of lead and cadmium accumulation of feral pigeons (Columba livia). Environmental Monitoring and Assessment, 95, 23-35.

[2] Abduljaleel SA, Shuhaimi-Othman M and Babji A. (2011). Variation in trace elements levels among Chicken, Quail, Guines Fowl and Pigeon Egg shell and Egg content. Journal of Environmental Toxicology, 5, 301-308.

[3] Sharma RK and Agrawal M. (2005). Biological effects of heavy metals: an overview. Journal of Environmental Biology, 26, 301-313.

[4] Khan RA and Thulin J. (1991). Influence of pollution on parasites of aquatic animals. Advances in Parasitology, 30, 201-238.

[5] Gabrashanska M and Nedeva I. (1996). Content of heavy metals in the system fish-cestodes. Parassitologia, 38, 58.

[6] Tenora F, Baruš V, Kráčmar S and Drořáček J. (2000). Concentration of some heavy metals in Ligula intestinalis plerocercoids (Cestoda) and Philometra ovata (Nematoda) compared to some their hosts (Osteichthyes). Helminthologia, 37, 15-18.

[7] Sures B, Knopf K, Würtz J and Hirt J. (1999). Richness and diversity of parasite communities in European eels Anguilla anguilla of the River Rhine, Germany, with special reference to helminth parasites. Parasitology, 119, 323-330.

[8] Baruš V, Simkova A, Prokes M, Penaz M and Vetesnik L. (2012). Heavy metals in two parasite-host systems: tapeworm vs. fish. Acta Veterinaria Brno, 81, 313-317. 
[9] Sures B, Scheible T, Bashtar AR and Taraschewski H. (2003). Lead concentrations in Hymenolepis diminuta adults and Taenia taeniaeformis larvae compared to their rat hosts (Rattus norvegicus) sampled from the city of Cairo, Egypt. Parasitology, 127, 483-487.

[10] Torres J, Peig J, Eira C and Borrás M. (2006). Cadmium and lead concentrations in Skrjabinotaenia lobata (Cestoda: Catenotaeniidae) and in its host Apodemus sylvaticus (Rodentia: Muridae) in an urban dumping site in Spain. Environmental Pollution, 143, 4-8.

[11] Tenora F, Baruš V and Prokes M. (2002). Next remarks to the knowledge of heavy metal concentrations in gravid tapeworm species parasitizing aquatic birds. Helminthologia, 39, 143-148.

[12] [12] Baruš V, Tenora F and Kráčmar S. (2000). Heavy metal (Pb, Cd) concentrations in adult tapeworms (Cestoda) parasitizing birds (Aves). Helminthologia, 37, 131-136.

[13] UNEP/FAO/IOC/IAEA. (1984). Determination of total cadmium, zinc, lead and copper in selected marine organisms by flameless atomic absorption spectrophotometry. Reference Methods For Marine Pollution Studies, 11.

[14] FAO/WHO. (2004). Summary of evaluations performed by the joint FAO/WHO expert committee on food additives (JECFA 1956-2003). ILSI Press International Life Sciences Institute, Washington.

[15] Sures B. (2007). Host-parasite interactions from an ecotoxicological perspective. Parasitology, 47, 173-176.

[16] Eissa IAM, Gehan IS, Wafeek M and Nashwa AS. (2012). Bioremediation for heavy metals in some Red Sea fishes in Suez, Egypt. SCVMJ, XVII, 341-356.

[17] Azmat R, Fayyaz S, Kazi N, Mahmood SJ and Uddin F. (2008). Natural bioremediation of heavy metals through nematode parasite of fish. Biochemistry, 7, 139-143.

[18] Madanire-Moyo GN and Barson M. (2010). Diversity of metazoan parasites of the African catfish Clarias gariepinus (Burchell, 1822) as indicators of pollution in a subtropical African River system. Journal of Helminthology, 84, 216-227.

[19] Forstner U and Wittmann GT. (1979). Metal Pollution in the Aquatic Environment. Springer-Verlag, New York, 117.

[20] Samuel D and George PV. (2000). Mineral constituents of freshwater fish Channa striatus infected with acanthocephalan parasite Pallisentisnag purensis. Indian Journal of Fisheries, 47, 215-224.

[21] Elnabris KJ, Muzyed SK and El-Ashgar NM. (2013). Heavy metal concentrations in some commercially important fishes and their contribution to heavy metal exposure in Palestinian people of Gaza Strip (Palestine). Journal of the Association of Arab Universities for Basic and Applied Sciences, 13, 44-51.

[22] Pourang N. (1995). Heavy metal bioaccumulation in different tissues of two fish species with regards to their feeding habits and trophic levels. Environmental Monitoring and Assessment, 35, 207-219.

[23] Miller TG and Mackay WC. (1980). The effects of hardness, alkalinity and pH of test water on the toxicity of copper to rainbow trout (Salmo gairdneri). Water Research, 14, 129-133.

[24] Bíreš J, Dianovský J, Bartko P and Juhásová Z. (1995). Effects on enzymes and the genetic apparatus of sheep after administration on samples from industrial emissions. BioMetals, 8, 53-58.

[25] Baruš V, Tenora F, Krácmar S and Dvorácek J. (1999). Contents of several inorganic substances in European eel infected and uninfected by Anguillicola crassus (Nematoda). Diseases of Aquatic Organisms, 37, 135-137.

[26] Ek KH, Morrison GM, Lindberg P and Rauch S. (2004). Comparative tissue distribution of metals in birds in Sweden using ICP-MS and laser ablation ICP-MS. Archives of Environmental Contamination and Toxicology, 47, 259-269.

[27] Gabrashanska M and Nedeva I. (1994). Microelement concentration of the host-parasite system Cyprinus capriocestods. Biotechnology and Biotechnological Equipment, 8, 54-57.

[28] Dural M, Genc E, Yemenicioğlu S and Sangun MK. (2010). Accumulation of some heavy metals seasonally in Hysterotylacium aduncum (Nematoda) and its host Red Sea Bream, Pagellus erythrinus (Sparidae) from Gulf of Iskenderun (North-Eastern Mediterranean). Bulletin of Environmental Contamination and Toxicology, 84, 125131. 
[29] Oyoo-Okoth E, Admiraal W, Osano O, Hoitinga L and Kraak MH. (2010). Metal specific partitioning in a parasitehost assemblage of the cestode Ligula intestinalis and the cyprinid fish Rastrineobola argentea. Science of the Total Environment, 408, 1557-1562.

[30] Dural M, Genc E, Sangun MK and Güner Ö. (2011). Accumulation of some heavy metals in Hysterothylacium aduncum (Nematoda) and its host sea bream, Sparus aurata (Sparidae) from North-Eastern Mediterranean Sea (Iskenderun Bay). Environmental Monitoring and Assessment, 174, 147-155.

\section{How to cite this article}

Abdel-Gaber R, Alzuabi Kand Abdel-Gaber R. (2020). The role of Ascaridia columbae in bioremediation of heavy metal accumulation in Columba livia tissues. World Journal of Advanced Research and Reviews, 5(3), 142-148. 